\title{
Creating Distinctive Value Proposition in Tourism by Business Model Tools: Case Study of the City of Ohrid
}

\author{
Stojan Debarliev, PhD Associate Prof. \\ Sanja Mitrovska, Teaching Assistant \\ Ss. Cyril and Methodius University in Skopje, \\ Faculty of Economics - Skopje
}

doi: 10.19044/esj.2016.v12n35p82 URL:http://dx.doi.org/10.19044/esj.2016.v12n35p82

\begin{abstract}
The purpose of this paper is creating distinctive value proposition and recognizable destination brand through integration of different activities and actors in the segment of tourism by application of a business model tool. To illustrate the application of the "Business model canvas" tool, it was taken a case study of the city of Ohrid, which is one of the most beautiful tourist destination on the Balkan Peninsula, protected by UNESCO, but at the same time confronted with many problems in tourism, as many tourist destinations in the world. Besides, the application of the methodology of "business model canvas", we carried out interviews and an empirical survey on "creators" and "consumers" of tourism in the city of Ohrid. The results of the overall research, the created tourist model of Ohrid, as well as the supported research instruments, interviews and empirical survey bring some interesting ideas and solutions for many contemporary issues in tourism, such as: integrated tourist offer that lasts 12 months, combined with diverse types of tourism, highly professional service and shared values, widely differentiated accommodation with clear targeting and positioning strategy, as well as focused tourist zones that cover certain type of tourism for a pleasant stay and experience e of tourists with necessary supporting services for the full functionality. The main idea is the wide diversity of offers to be integrated into one story, supported from citizens as well as from all key partners who believe in the city brand called Ohrid.
\end{abstract}

Keywords: Value proposition, destination brand, business model, tourism, city of Ohrid 


\section{Introduction}

Well-developed tourism in one country brings increased employment, economic diversification, infrastructure development and helps solving a global problem-redistribution of wealth from metropolis to peripheral areas. Fully exploitation of tourist potential through exploring and developing a brand of tourist destinations is an issue of special concern in every country.

The main problem that arises in the efforts and attempts of "creators" of tourism in most of the tourist destinations is disintegration of the activities and measures designed to promote tourism. Many "creators" of tourism fail to provide added value for "consumers" of tourism, bringing all the parts in distinctive tourist brand. In order for a city to be a good brand, it must possess defining and distinctive characteristics that can be readily identified. These are functional as well as non-functional qualities. They include city appearance, people's experience of the city, people's belief in the city, what the city stands for, and what kind of people inhabit the city. Creating a distinctive brand that captures the spirit of a city must be able to inspire the travelers, the industry and the general populace itself.

Creation of a complete and distinctive story, brand and reputation of tourist destinations is a real challenge of contemporary tourism. The only thing needed for those destinations is to be understood as a specific "business" entity, which then can be approached by applying business analytical tools as in any other successful story in the field of business.

Business model is an approach, applied mostly by companies when presenting all deliverables that have to be met in order to create a product or service. The Business Model Canvas, is a one of the most comprehensive strategic management and entrepreneurial tools that allow to describe, design, challenge, invent, and pivot business models. It provides a systematic view of the "big picture" composed of wide range of products or services (value proposition). Subsequently the question on why the tools about managing private and public sector are viewed separately is naturally imposed. At the end of the day, every president or mayor is a manager of an "organization" which needs to "promote and sell" its own "products or services" - (tourism, opportunities for foreign direct investment, strategic partnerships with different stakeholders, etc), providing added value to "consumers". In the case of tourism, the mayors of cities should coordinate and integrate the separated activities of "creators" of tourism (government, municipality, citizens, caterers, travel agencies, agencies for support and development of tourism) in one tourist model, bringing added value to the tourists. 
The main hypothesis of the research is the integration of different activities and actors into one brand story in the segment of tourism, which can create distinctive value proposition for the "consumers" of tourism.

The purpose of the paper is creating distinctive value proposition and recognizable destination branding, through integration of different activities and actors in the segment of tourism by application of business model tools. To illustrate the application of the business model, it was taken a case study of the city of Ohrid, one of the most beautiful tourist destination on the Balkan Peninsula, protected by UNESCO (because of the many sights and natural beauties that possesses) and in the same time confronted with many problems in tourism, as many tourist destinations in the world.

The impact for "creators" of tourism worldwide, is the awareness that by implementing the knowledge about "business model canvas" in tourism (combining the public and private sector), suitable solutions for many contemporary issues in tourism could be developed.

\section{Literature review}

\section{The concept of the business model and "business model canvas"}

The Ovans's (2015) review of HBR's archives about the subject of business model, shows the many ways business thinkers use the concept and define the term. The author of the review begins with Lewis (1999), who offers up the simplest of definitions - "All it really meant was how you planned to make money". Also in this regard, Drucker (1994) defined the term - "assumptions about what a company gets paid for" - which is part of Drucker's "theory of the business". Still, Drucker (1994) is more interested in the assumptions of a business concept than the money. Magrettain (2002) "Why Business Models Matter" explains that business models are "at heart, stories - stories that explain how enterprises work. Osterwalder (2010) has developed one of the most comprehensive template on which to construct the assumptions i.e. hypotheses of a business model. His nine-part "business model canvas" is essentially an organized way to lay out assumptions about the key resources, key activities and key partners as parts of value chain, but also value proposition, customer relationships, channels, customer segments, cost structures, and revenue streams. Similarly, the approach of Christensen (2008), known as disruptive innovation begins by focusing on the customer value proposition - what Christensen (2008) calls the customer's “job-to-be-done.”, and It then identifies those aspects of the profit formula, the processes, and the resources that make the rival offering not only better, but harder to copy or respond to. In "Four Paths to Business Model Innovation," Giotra and Netessinewrite (2014) about creating a new model by altering current business model in four broad categories: by changing the mix of products or services, postponing 
decisions, changing the people who make the decisions, and changing incentives in the value chain. In "How to Design a Winning Business Model,” Cassadesus-Masanell and Ricart (2011) focus on the choices managers must make when determining the processes needed to deliver the offering, dividing them broadly into policy choices, asset choices and governance choices.

As it is mentioned above, Osterwalder (2010) has developed one of the most comprehensive strategic management tool to design, test, build, and manage (profitable and scalable) business models. This concept offers shared language that allows to easily describe and manipulate business models to create new strategic alternatives. According to the "business model canvas" a business model can best be described through nine basic building blocks that show the logic of how a company intends to make money. The nine blocks cover the four main areas of a business: customers, offer, infrastructure, and financial viability. The customer segments building block defines the different groups of people or organizations an enterprise aims to reach and serve. The value propositions building block describes the bundle of products and services that create value for a specific Customer Segment. The channels building block describes how a company communicates with and reaches its customer segments to deliver a value proposition. The customer relationships building block describes the types of relationships a company establishes with specific customer segments. The revenue streams building block represents the cash a company generates from each customer segment (costs must be subtracted from revenues to create earnings). The Key resources building block describes the most important assets required to make a business model work. The key activities building block describes the most important things a company must do to make its business model work. The key partnerships building block describes the network of suppliers and partners that make the business model work. The cost structure describes all costs incurred to operate a business model.

\section{The importance of destination branding for promotion of tourism}

The competitive environment is a reality of our times, and how a city or place stakes out and communicates its distinctiveness, mainly decides which ones succeed and which fail in the race for economic prosperity. Places are just like companies: strong city brand provides easier way of selling products and services, and attracting people and investments. "In today's globalized, networked world, every place has to compete with every other place for its share of the world's consumers, tourists, businesses, investment, capital, respect and attention.” (CEOs for Cities, 2006).

According to the American Marketing Association (2004), a Brand is a "name, term, sign, symbol, design, or a combination of them, intended to 
identify the goods and services of one seller or a group of sellers and to differentiate them from those of competition”. Khanna (2011) states that "brands go much beyond the connotation of type and source of identification”. Brands evoke familiarity and feelings in the minds of the consumer providing reputation and revenue for the company that created the brand. The purpose of branding is to achieve consumer perception that will deliver a sustainable competitive advantage (Gardyn, 2002).

When we talk about branding, we need to differentiate destination branding from product/service branding because of the diverse approaches used in the branding process. So, what is the difference between a destination brand and regular product or service brand? According to Gnoth (2002), "destination branding is the management process which leads to a strategic plan to build brand identity based upon destination attributes selected on the basis of competitiveness, uniqueness and desired identity."

Hall (2000) identifies a destination as a "well-defined geographical location such as a city or a country." Buhails (2000) expands Hall's definition to include "a concept, a perceived idea of what a destination could be in the eyes of the customer based on travel plans or past experiences not bound by geographical locations". Consequently, a destination is "a plethora of interrelated elements and experiences” (Murphy et al. 2000). Accordingly, as pointed out by Silkes (2007), “destination branding is the selection and implementation of consistent elements to identify and differentiate a place through positive image building”.

"Every place is unique by itself and destinations are not homogenous places. Branding these complex entities takes much more than a cookie cutter approach or an afternoon brainstorming session. What may work in revealing and building the brand for one community, may not necessarily work in another" (Baker, 2007). Silkes (2007) goes further when stating that destination branding is amongst the most complex branding process, as the stakeholders include both public and private organizations, local residents and foreign citizens. This idea is picked by Baker, who considers there are very close emotional ties between people and the places they live in, and this is a special dimension to consider when applying branding and marketing practices to a community, as opposed to applying them to goods. Whether as residents or visitors, people have very special bonds to places (Baker 2007).

According to Winfield-Pfefferkorn (2005) the following traits are characteristics of strong brand that cities need if they are to develop as brands on their own: functionality, added value and integration. Functionality means observable benefits. A city must function as a destination for employment, industry, housing, public transportation, and recreational attractions. Added value can come in many forms, most of them non-functional and emotional and not as quantifiable as the functional ones. 
The added values that brands must have in order to succeed are: people's experience of the city, perception: how is the population perceived?, belief in the city: does it stand for something? and appearance: what does the city look like? Finally, a city must be integrated in order to have a good brand. What many unknown or poorly branded cities forget in their planning stages is that sameness is mundane and boring. Urban planning and development with cohesiveness are often necessary and always look good on paper, but in order for people to get excited about living somewhere there has to be diversity.

\section{Current situation of the city of Ohrid}

Government measures for encouraging the development of tourism gave some results, and this positive trend is statistically noted. In the recent years the attendance of foreign guests has increased by more than 100 percent, and earnings from tourism exceeded 100 million in 2014. This sector had an annual turnover of 333.8 million euro, of which 221.9 million euro belong to foreign guests, and the other 111. 9 million come from Macedonian tourists. The National Strategy for Tourism Development predicts that tourism by 2020 will contribute with 5 percent to the gross domestic product (GDP) compared with its current 2.3 percent of GDP (Subventions great incentive for bringing foreign tourist by travel agencies, 2016).

The southwest region of Macedonia is a natural perfection with rich fields, mountains full of vegetation, peaks as high as $2000 \mathrm{~m}$ full of rivers, high canyons, natural and artificial lakes as well as an authentic cultural heritage. This region has been attractive for many civilizations leaving their trails and marks that are visible at present day. In average above $42 \%$ of all tourist arrivals and 62\% overnight stays in Macedonia happen in the Southwest region. The main tourist center in the region is Ohrid and the surroundings of Ohrid Lake (Municipality of Ohrid - Unit for local economic development, 2014).

Ohrid has acquired its affirmation since the period when Macedonia was part of Yugoslavia. For the popularity Ohrid had in the past testify the range of existing hotels which at that time were resorts of large firms. The reasons for such actions from the firms were obvious - great location, altitude, unusual climate, proximity, were just part of something in what they enjoyed. In its golden era in the 1990s, the annual attendance in the city had always been more than 1.1 million visitors. The dissolution of Yugoslavia, the critical political and economic situation in the Balkan peninsula, was the main cause of a dramatic drop in the attendance of tourists in the city, something that should not have happened if Ohrid, as an entity would had had a clear picture of where it should be positioned in the future and has 
been accordingly managing its resources Beside the stabilization of the situation in the region, Ohrid still lags step behind trends and still cannot come even close to reaching the level of attendance which was present in the past.

Traditionally, Ohrid's most numerous guests come from neighboring Serbia, Greece, Bulgaria and besides the summer season they visit Ohrid in great Christian holidays, Easter and Christmas. In recent years, the number of Turkish guests and other European countries has increased as well. Even before the summer season starts, guest from the Netherlands visit Ohrid like in the old days, or so called ,golden age" of Ohrid tourism. According to statistics, the last two years the number of foreign tourists from Benelux countries, China, Japan, Turkey, Russia and Poland has increased as well.

On the other hand, the reduced number of travel arrangement to Ohrid by domestic travel agencies results from the following factors: high price or incorrect proportion between price and quality, legally regulated private accommodation and inadequate presentation of the beauty of Ohrid by unqualified guides. Subventions that government of Macedonia provides for foreign travel agencies are important, but according to hoteliers these subventions should go to domestic travel agencies also, in order to improve their cooperation with hotels. The main competitors of Ohrid are Greece and Bulgaria that offer far more competitive prices for accommodation. Incorrect proportion between price and quality of accommodation in Ohrid creates frustration among tourists, being aware that for that price they would receive better accommodation in the neighborhood.

To leverage the high potential of tourism for economic and social development of The Republic of Macedonia, the Association of Hoteliers believes that is urgently necessary to take more short-term, but also longterm measures. University professors Sasho Korunoski and Naum Marinoski from Faculty of Tourism and Hospitality in Ohrid, consider that for the development of tourism are needed realistic strategies, educated and professional staff, as well as promotion and proper evaluation of the tourist area (Macedonian tourism overcomes barriers to development, 2016).

As it is mentioned in the introduction, the main problem that arises in the efforts and attempts of "creators" of tourism in most of the tourist destinations are unintegrated activities and measures designed to promote tourism. Besides, some encouraging trends in the last few years, the city of Ohrid is confronting with many problems in tourism, such as: short tourist season, unstable and unpredictable number of tourists, lack of consistent story, as well as some functional and infrastructural issues. 


\section{Methodology \\ Data and sample}

For the purposes of our research work, we carried out an interviews and an empirical survey on those who are directly involved in the creation of tourism in Ohrid i.e. "creators" and "consumers". They comprise: City Administration, Agency for Support and Development of Tourism, caterers (hoteliers, restaurants and nightclubs), travel agencies, tourists and citizens of the city. Questionnaires were designed for all the above stakeholders, while interviews were intended solely for the creators of the offer of the city. The questionnaires were delivered in two ways: personally and through the online platform Survey Monkey. Interviews, unlike the surveys were only made personally. We received responses from: 204 tourists, 50 citizens, 10 hoteliers, 10 restaurants, 10 nightclubs, 5 representatives from city administration and 10 travel agencies. In order to keep the attention of the respondent, but to obtain implicit information about the positioning of the city, we decided to compose questionnaires that include four universal questions about the reasons why tourists are coming, the age of tourists that are coming, the shortcomings of the city and what the caterers are known by. The results from the surveys are presented as an average ranking from 1 to 5 for each offered answer, where 1 is considered as lowest and 5 as highest score.

In addition to the primary data sources we used secondary data sources: World heritage list on the web page of UNESCO, where we found about cultural heritage of the Ohrid region, CNN report about Ohrid lake and Ohrid - the root of Christianity, web page of Agency for Promotion and Support of Tourism, where we found the investments opportunities and projects for promotion of Macedonian tourism, web page of Guardian where we looked on travelogue called „A dive into Macedonia’s past at Lake Ohrid".

\section{Research approach}

After the data processing, and presentation of the main results, in the second part the paper, the data and results are used for applying the "business model canvas" tool in order to create the tourist business model of city of Ohrid. This model should demonstrate the "big picture" of the city as an integrated product of individual stakeholders’ goods and services, expressing the main ideas of authors for creating distinctive value proposition, designed to promote the tourism of city of Ohrid.

\section{Results and analysis}

Based on the proceeded data of the conducted survey, already visible problems, deficiencies, weaknesses were confirmed, but also new problems 
became visible thanks to the examination of all key stakeholders. In order to provide simplified presentation of results, the interviewed stakeholders were divided in two groups 1) creators of tourism (City Administration, Agency for Support and Development of Tourism and caterers and 2) consumers of tourism (tourists and travel agencies).

The first question of interest of the survey is the main reason for visiting Ohrid. The respondents were given six different reasons for visiting Ohrid, as follow: lake and beaches, low prices, cultural and historical heritage, natural beauty/amenities, gastronomy and night life.

According to the results, the natural beauty/amenities and the cultural and historical heritage are top listed as motives for visiting Ohrid. In this regard, the both groups, the "creators" and the "consumers" have similar perception for the main reasons for visiting Ohrid, ranking this two reasons with average score from 4.7 to 4.9 on 5-points scale. On the other hand, the low prices and night life are fairly less important motives for visit. The respondents ranked this two reasons with average score from 2.3 to 3.0 points.

Figure 1: Which is the main reason for visiting Ohrid?

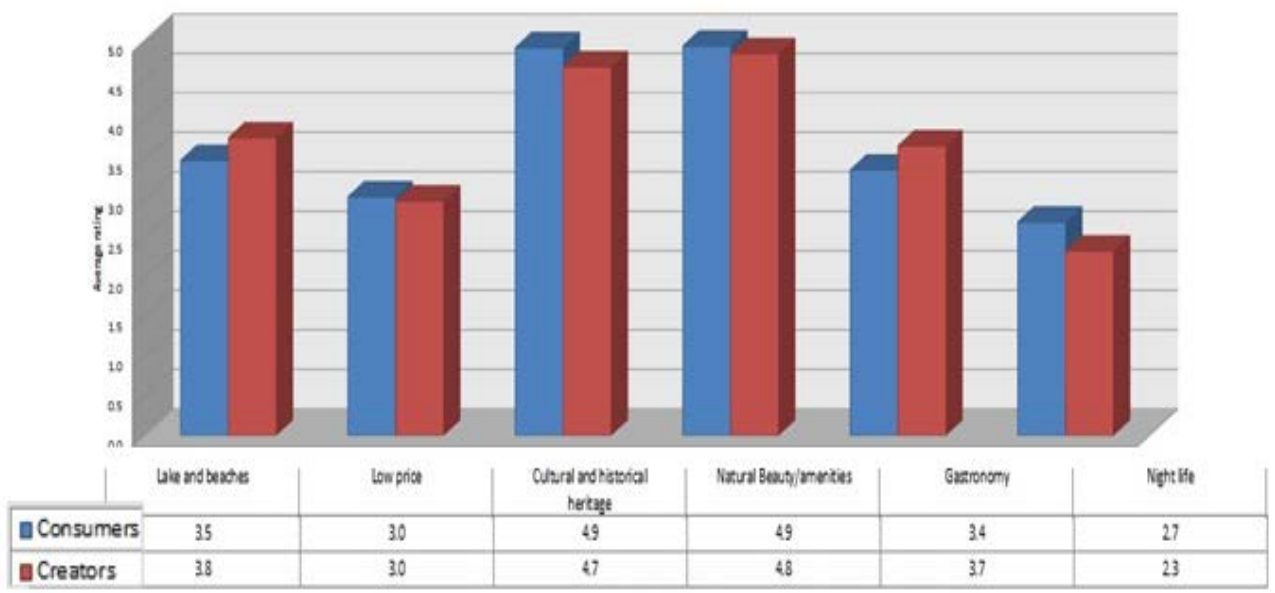

Source: Authors’ analysis

The biggest difference between perceptions of the both groups of respondents is noted in their perception of the night life as a reason for visiting Ohrid. Although both groups ranked this question with the lowest score, still the group of "creators" has an average score 2.3 unlike the group of "consumers" who have average score 2.7 (figure 1).

For the purpose of getting a better profile of the tourist visitors of Ohrid, the age groups of tourists were examined. In this question, the tourists in Ohrid were divided in five age groups, as follow: up to 18 years, from 18 to 30 years, from 30 to 50 years, from 50 to 65 years, and above 65 years. 
This question seems to be essential for the purpose of creating the story of Ohrid, since the different age groups should manifest different preferences.

The results are the following: it is noticeable that two age groups dominate 1) from 30 to 50 years, tourists that are interested in the congress tourism, and 2) from 50 to 65 years, tourists who all together with the tourists aged above 65 represent the target group that is interested in visits of cultural and historical destinations.

Figure 2: What age are the tourists in Ohrid?

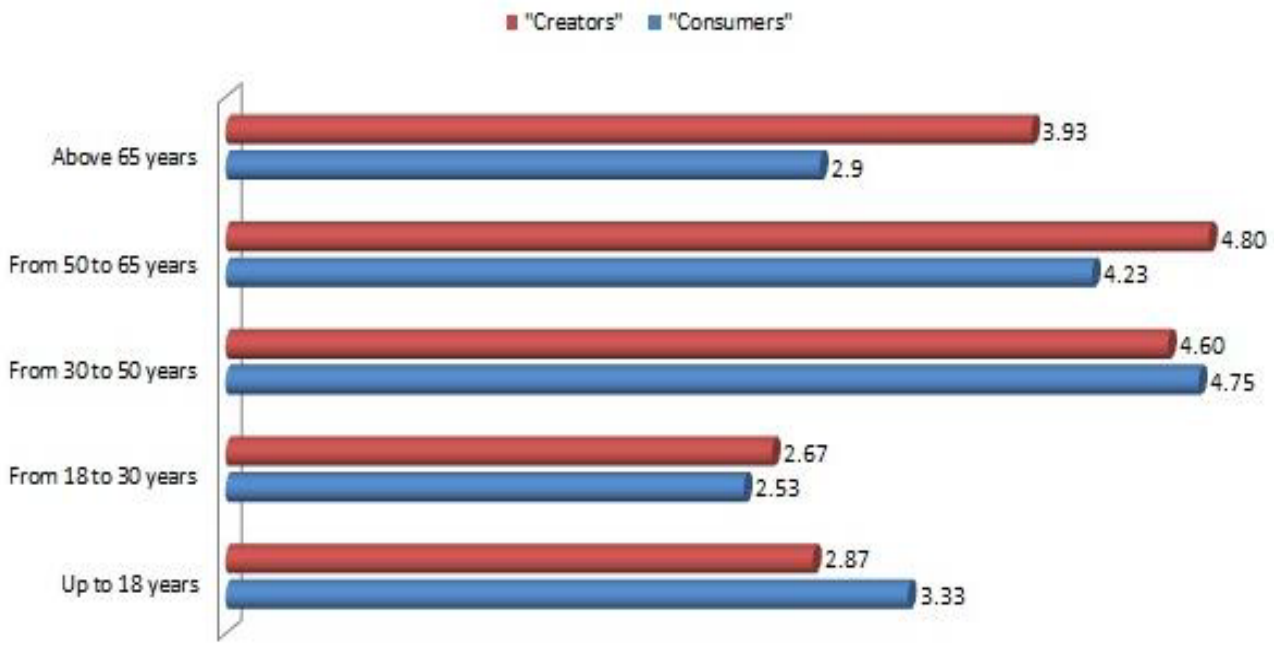

Source: Authors’ analysis

Since the answers of this question are based on perception of the both groups of respondents ("creators" of tourism and "consumers" of tourism) it is very interesting that there is a noticeable large difference in perception of "consumers", i.e. tourists in relation to perception of "creators", particularly in presence of age groups "from 50 to 65 years" and "above 65 years", as well as age group "up to 18 years". Namely, the "consumers" believe that the age group "above 65 years" is not so present in Ohrid, instead the age group "up to 18 years", which is more present in the tourist life of the city. Still, according to perception, and probably the more informed "creators", the age groups "from 50 to 65 years" and "above 65 years" are more frequent visitors of Ohrid then the age group "up to 18 years", as it looks in the eyes of the tourists (figure 2).

The research is continued towards finding out what the caterers are known by, or even better how the "consumers" perceive the consumption of Ohrid as a package of offers. 
Figure 3: What are the caterers in Ohrid known by?

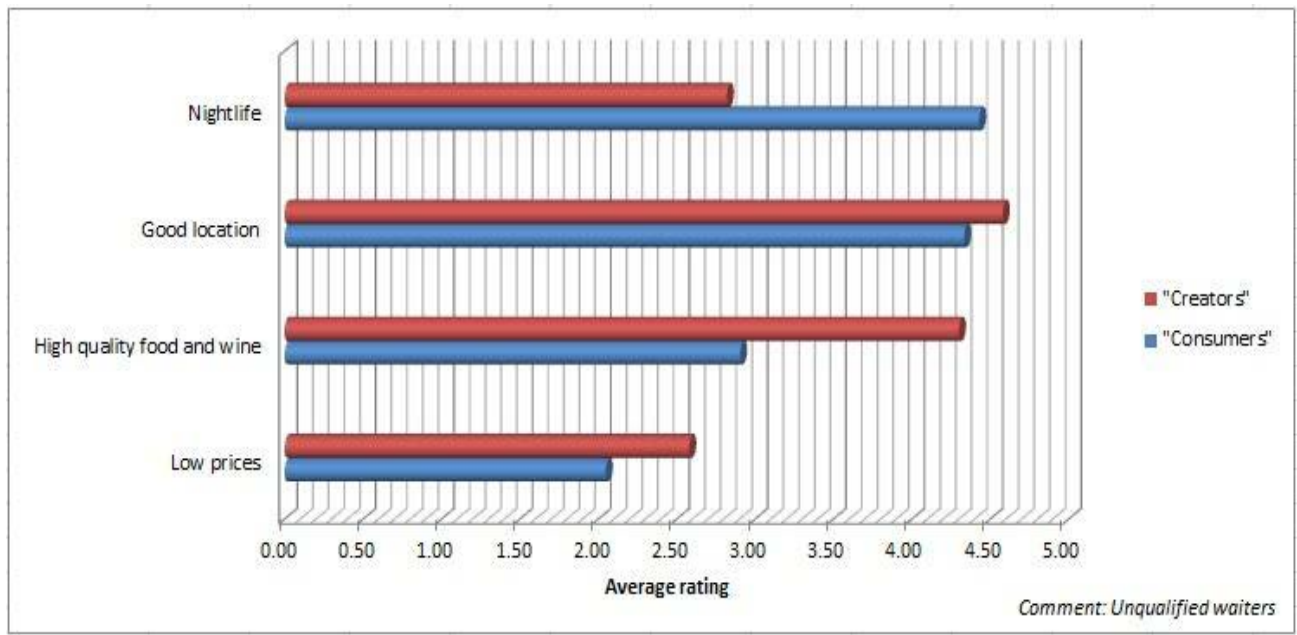

Source: Authors’ analysis

The interpretation of the results shows that what seems to be the main reason for "what the caterers are known by" for the "consumers" - night life (ranking this reason with average score of 4.4 points on 5-point scale) is assessed as the second low rated reason for the "creators: of tourism (ranking this reason with average score of 2.8 points on 5-point scale). Also, the perception is considerably different for the quality of food and wine. "Creators" believe in high quality food and wine as a one of the main features of caterers with average score of 4.3 points, unlike the "consumers" who assessed this reason with average score of 2.9 points. But both, "creators" and "consumers" of tourism have the same opinion that caterers are not known for their low prices (figure 3)

Furthermore, the perception of the "consumers" and "creators" were analyzed by asking them to what do they see as a shortage of Ohrid. The respondents were given six different reasons for visiting Ohrid, as follow: tourist program for 12 months, luxury hotels, nightlife, clean and tidy beaches, catering culture, and good infrastructure.

Tourist offer that will last 12 months is listed as a primary deficiency. The respondents ranked this shortage with average score from 4.7 to 4.8 on 5-points scale. Caterers' culture is a second listed deficiency (with average score of 4.7 points), while clean and tidy beaches, from the "consumers" are perceived as third listed shortage (with average score of 3.8 points). On the other hand, the "creators" oppose the idea that neat beaches are important, they believe that tourists come to Ohrid to enjoy its architecture, rich history and culture. The results show confrontation between "consumers" and "creators" of tourism, also in the shortages related to luxury hotels, nightlife 
and good infrastructure. In all three cases, the "creators" believe that the conditions are more decent than they actually looks in the eyes of the “consumers”, i.e. tourist (figure 4).

Figure 4: What is the shortage of Ohrid?

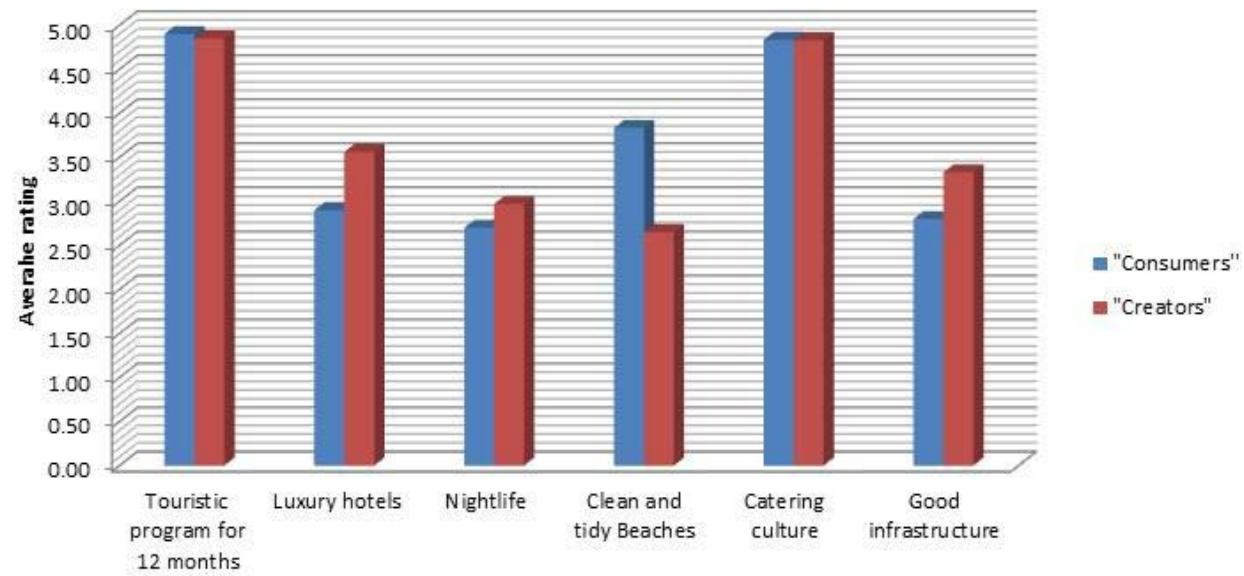

Source: Authors' analysis

\section{Integration of actors and activities into tourist model of Ohrid}

Different ideas, activities and actors from the previous phase were implemented using the "business model canvas" tool into a tourist business model, which should demonstrate the "big picture" of the city as an integrated product of individual stakeholders' goods and services (figure 5).

"Business model canvas" tool covers 4 business segments (supply, consumers, structure, and financial sustainability) presented in 9 blocks, as follow: customer segments, value proposition, customer channels, customer relationships, revenue streams, key resources, key activities, key partnerships and cost structure (Osterwalder and Pigneur, 2010).

The central position is taken by the supply, or value proposition, which is a key element in the business model. The construction of a business model starts with customer segment/s, a company (or any other entity which crates value) intends or hopes to address with the value proposition. This practically means, the tourists who visit and the tourist who could visit Ohrid are identified and selected and then their profile is created.

\section{Customer segments}

In order to identify the main customers segments, we rely on results from the research, comprises of an interview and empirical survey on those who are directly and indirectly involved in the creation of tourism in Ohrid i.e. "creators" of tourism and the tourists i.e. "consumers" of tourism.

For this purpose, we first asked respondents about the demographics of tourists in terms of their age in order to find the dominant demographic 
groups of tourists who visit Ohrid. Than we use the approach of segmentation and targeting of customers according to the methodology of "business model canvas", where the customer (segment) profile describes a specific customer segment in a business model in a more structured and detailed way. It breaks the customer down into its jobs, pains, and gains. Customer jobs describe what customers are trying to get done in their work and in their lives (Osterwalder and Pigneur, 2014). In order to identify the main tourist "jobs" and ultimately to discover the additional groups of tourists who visit Ohrid or could visit Ohrid as potential customer segments, we asked respondents about the main reasons for visiting Ohrid. The results show that two age groups dominate, the first group from 30 to 50 years, and the second group from 50 to 65 years, who together with the tourists aged above 65 years could represent a target group interested in a similar tourist offer. Since, most of the responses to the question about the main reasons for visiting Ohrid lead to cultural and historical heritage as top listed motive, we identify the first customer segment, which includes tourists aged from 50 to 65 years and above 65 years, who are interested for cultural heritage tourism, with special emphasis on church tourism, mostly foreign tourists. From the tourist group aged from 30 to 50 years three different customer segments could be formed, depending on their prevalent reasons for visiting Ohrid. The first customers segment cold be interested for alternative tourism with focus on rural or increasingly popular eco and active tourism (as travelling philosophy that combines adventure, ecotourism and cultural aspects of a discovery tour), since the natural beauty/amenities is top listed as reason for visiting Ohrid. Second customer segment could be interested for lake tourism, which is consists of families, mostly aged from 30 to 50 years, who rank the lake and beaches highest on their reasons for visiting Ohrid. Third customer segment is professionally motivated people, from 30 to 50 years, who visit Ohrid for attending on different types of conferences, congresses and training and development program for HR, practically interested for congress tourism.

Figure 5: Tourist model of Ohrid

\begin{tabular}{|c|c|c|c|c|}
\hline $\begin{array}{c}\text { Key Partners } \\
\text { City } \\
\text { Administration } \\
\text { Agency for } \\
\text { Support and } \\
\text { Development } \\
\text { of Tourism } \\
\text { Caterers } \\
\text { (hoteliers, } \\
\text { restaurants and } \\
\text { nightclubs) }\end{array}$ & $\begin{array}{l}\text { Key Activities } \\
\text { Activities that } \\
\text { should be } \\
\text { undertaken for } \\
\text { integration and } \\
\text { synchronization of } \\
\text { the tourist offer of } \\
\text { Ohrid: } \\
\text { Collaboration and } \\
\text { setting goals } \\
\text { between different }\end{array}$ & $\begin{array}{l}\text { Value Proposition } \\
\text { Integrated tourist } \\
\text { offer combined of } \\
\text { diverse types of } \\
\text { tourism } \\
\text { Cultural heritage } \\
\text { tourism } \\
\text { Alternative tourism } \\
\text { (rural, eco and } \\
\text { active tourism) } \\
\text { Lake tourism }\end{array}$ & $\begin{array}{c}\text { Customer } \\
\text { Relationships } \\
\text { Integrated story } \\
\text { into one brand } \\
\text { called Ohrid } \\
\text { Support from } \\
\text { citizens and } \\
\text { belief in the city } \\
\text { brand } \\
\text { Different forms } \\
\text { of }\end{array}$ & $\begin{array}{c}\text { Customer } \\
\text { Segments } \\
\text { Tourist group } \\
\text { aged from } 50 \text { to } \\
65 \text { years and } \\
\text { above } 65 \text { years } \\
\text { Segment } \\
\text { interested in } \\
\text { cultural heritage } \\
\text { tourism } \\
\text { Segment }\end{array}$ \\
\hline
\end{tabular}




\begin{tabular}{|c|c|c|c|c|c|}
\hline $\begin{array}{l}\text { Educated and } \\
\text { professional } \\
\text { diverse tourist } \\
\text { workers } \\
\text { Travel } \\
\text { agencies } \\
\text { Tour operators } \\
\text { Clusters and } \\
\text { institutions } \\
\text { directly related } \\
\text { to the different } \\
\text { types of } \\
\text { tourism } \\
\text { Citizens of } \\
\text { Ohrid } \\
\text { “Creative } \\
\text { class” whose } \\
\text { economic } \\
\text { function is to } \\
\text { create new } \\
\text { ideas and } \\
\text { creative } \\
\text { contents }\end{array}$ & $\begin{array}{c}\text { Natural } \\
\text { beauty/amenities } \\
\text { Beautiful Ohrid } \\
\text { Lake, pleasant } \\
\text { climate, national } \\
\text { park Galichica } \\
\text { Cultural and } \\
\text { historical heritage } \\
\text { Rich historical } \\
\text { heritage, 365 } \\
\text { churches, specific } \\
\text { architecture of } \\
\text { Ohrid } \\
\text { Appropriate } \\
\text { structure of } \\
\text { accommodation } \\
\text { and services } \\
\text { Facilities and } \\
\text { recreational } \\
\text { attractions } \\
\text { Suitable } \\
\text { infrastructure with } \\
\text { connected roads, } \\
\text { parking places and } \\
\text { public transport }\end{array}$ & \multicolumn{2}{|c|}{$\begin{array}{l}\text { Congress tourism } \\
\text { Integrated tourist } \\
\text { offer that will last } 12 \\
\text { months } \\
\text { Service with high } \\
\text { level of } \\
\text { professionalism and } \\
\text { shared values } \\
\text { Widely } \\
\text { differentiated } \\
\text { accommodation } \\
\text { with clear targeting } \\
\text { and positioning } \\
\text { strategy } \\
\text { Higher-class hotels } \\
\text { with suitable } \\
\text { standards and } \\
\text { requirements } \\
\text { Middle-class hotels } \\
\text { with promotional } \\
\text { arrangements in low } \\
\text { session periods } \\
\text { Hotels for } \\
\text { professional events } \\
\text { with appropriate } \\
\text { space conditions, } \\
\text { ICT support and } \\
\text { other required } \\
\text { facilities } \\
\text { Visible and } \\
\text { regulated privet } \\
\text { accommodation } \\
\text { All-inclusive hotel } \\
\text { resorts } \\
\text { Focused tourist } \\
\text { zones that cover } \\
\text { certain type of } \\
\text { tourism for pleasant } \\
\text { stay and experience } \\
\text { of tourists with } \\
\text { necessary } \\
\text { supporting services } \\
\text { for the full } \\
\text { functionality } \\
\text { a }\end{array}$} & $\begin{array}{l}\text { Original and } \\
\text { distinctive story } \\
\text { of the city, } \\
\text { communicated } \\
\text { and delivered to } \\
\text { a customer } \\
\text { segments } \\
\text { through: } \\
\text { Travel agencies } \\
\text { Tour operators } \\
\text { On-line booking } \\
\text { Mobile } \\
\text { application } \\
\text { Web portals } \\
\text { Website of the } \\
\text { city } \\
\text { A variety of } \\
\text { constant lines by } \\
\text { air, road and sea, } \\
\text { Websites } \\
\text { directly related } \\
\text { with various } \\
\text { types of tourism }\end{array}$ & $\begin{array}{l}\text { interested in } \\
\text { alternative } \\
\text { tourism } \\
\text { Tourist group } \\
\text { aged from } 30 \text { to } \\
50 \text { years } \\
\text { Segment } \\
\text { interested in } \\
\text { alternative } \\
\text { tourism } \\
\text { Segment } \\
\text { interested in lake } \\
\text { tourism } \\
\text { Segment } \\
\text { interested in } \\
\text { congress tourism } \\
\text { Tourist group } \\
\text { aged from } 18 \text { to } \\
\text { 30 years } \\
\text { Segment } \\
\text { interested in art } \\
\text { and } \\
\text { entertainment } \\
\text { Segment } \\
\text { interested in lake } \\
\text { tourism }\end{array}$ \\
\hline \multicolumn{3}{|c|}{$\begin{array}{l}\text { Costs for accommodation and services included } \\
\text { in the specific arrangement } \\
\text { Cost for facilities and recreational attractions for } \\
\text { different types of tourism } \\
\text { Investments in infrastructure } \\
\text { Marketing costs } \\
\text { Many other costs, crucial for functioning of the } \\
\text { tourist business model of city of Ohrid }\end{array}$} & \multicolumn{3}{|c|}{$\begin{array}{l}\text { Revenues from accommodation and services } \\
\text { included in the specific arrangement } \\
\text { Tickets by visits to historical and cultural } \\
\text { objects, events, recreational attractions } \\
\text { Selling souvenirs } \\
\text { Many other sources of revenues }\end{array}$} \\
\hline
\end{tabular}

Source: Model proposed by authors 
Further, we asked respondents about the main shortages of Ohrid, in order to reveal the "pains" as bad outcomes, risks, and obstacles related to customer jobs. Finally, in order to revel some of the "gains" (the outcomes customers want to achieve or the concrete benefits are seeking), we asked the respondents what the caterers in Ohrid are known by. Also, for the purpose of identification of the main tourists" "pains" and "gains", we use the information gained from the interviews, which were intended solely for the "creators" of tourism (City Administration, Agency for Support and Development of Tourism, caterers (hoteliers, restaurants and nightclubs) and travel agencies).Tourist offer that lasts 12 months was listed as a primary shortage, followed by low level of caterers' culture i.e. professionalism. Also there are shortages related to lack of visibility and better regulated privatebased accommodation, unsynchronized 'tourist" traffic, frequent sessional variation and high picks of number of tourists during the weekends and national holidays with frustrating jams as well. Regarding the main "gains" as expected or desired outcomes customers want to achieve, tourists of Ohrid would like to see affordable middle-level categorized hotel accommodation (especially for the domestic tourists), more luxury hotels (especially for the foreign tourists), appropriate infrastructure, as well as clean and tidy beaches.

\section{Value proposition}

After identifying and describing the main customer segments with their "jobs", "pains" and "gains", the next step in the "business model canvas" methodology i.e. the second part of the value proposition canvas is creating a value proposition for the targeted customer segments. Customer value represents the set of value proposition benefits that the company designs to attract customers, or customer value proposition describes the benefits customers can expect from the products and services (Osterwalder and Pigneur, 2014). Hence, the value (proposition) map describes the features of a specific value proposition in the business model in a more structured and detailed way. It breaks the value proposition down into products and services, pain relievers, and gain creators.

The part of products and services is a list of all the products and services a value proposition is built around. Starting from the main "customer jobs" the tourists of Ohrid try to get done, this part could consists of the following products and services: cultural heritage tourism, alternative tourism (rural, eco and active tourism), lake tourism and congress tourism. Knowing that Ohrid is rich with natural and cultural heritage, the religious, spiritual, alternative and rural tourism are something that this region should pay attention to, offering specifically designed package for tourists interested in those areas. The second and third part of the value proposition map is the 
part of "pain relievers", which describe how products and services alleviate customer pains, as well as "gain creators" which describe how products and services create customer gains. Practically, these two parts should offer solutions and opportunities for the main obstacles and frustrations the tourists want to avoid and benefits and outcomes they want to gain for the highest customer experience during their stay in Ohrid.

Tourist offer that will last 12 months is the highest priority and the ultimate objective of the widely integrated tourist offer of city of Ohrid. The absence of unified vision and clear positioning of the city, impacts the creators of tourism to deliver separated offers. An offer that is not integrated is seen as a dysfunctional whole without its own story. Not integrated, "creators" of tourism represent pieces that are difficult to match and create synergetic effect.

The tourists of Ohrid primarily expect high level of professionalism and cultural values at all "creators" of tourist offer. Education and professionalism of different types of tourist workers such as: Individual travel intermediaries, tour guides, managers and stuff in the hotels, restaurants, other involved workforce as well as city administration, agency for support and development of tourism and travel agencies is essential for real presentation of the beauties of Ohrid.

Zoning of the city is one possible solution for one of the main frustrations of the tourists of Ohrid, unregulated tourist "traffic". Not integrated offers attract different kind of tourists, mostly with opposite preferences. While one group of tourists visit Ohrid attracted by the nightlife and noise, other group of tourists come to Ohrid to consume its rich cultural and historical heritage. The chaos in Ohrid arises from the mix of these two main groups of tourists that bother each other. Physical zoning in a part of the city that has, for example parameters for cultural tourism assumes to locate facilities on certain standards that cover this type of tourism, instead of positioning the fun zone for youths. Despite the physical zoning, also it is necessary logistical zoning, which includes providing all necessary supporting services for the full functionality of a single zone (public transportation, tour guide, traditional food, etc.).

Since there are different defined customers segments with their own needs, desires and expectation, their accommodation should be widely differentiated. Despite the improvement of professionalism, the current hotels, most of them categorized from 3 to 4 stars, should create very clear targeting and positioning strategy. This means that they should find their customer segment and to specialize their offer for that segment. Practically, the hotels that strive to attract the foreign tourists or higher class of domestic touristc should increase their overall conditions, standards and requirements. Then,the hotels that strive to attract the middle class of domestic tourists 
should create different types of promotional arrangements, especially for national holidays in the low session periods. The hotels that strive to attract the professional motivated domestic tourists, who attend on different types of conferences, congresses and training and development programs for HR, should modify and adjust their concept in order to offer adequate conditions for different types of professional events, such as: congress halls, meeting rooms, ICT support and other required facilities. For the lower class segment, the private accommodation is mostly suitable, but there is lack of visibility and proper regulation of this segment. Since this type of accommodation is very little present in the offers of tourist agencies and even more on the different sources on the internet, the effort should be focused on creation of different types of web portals (such as booking.com) which will put the overall offer in one place, accessible for very wide range of people. Finally, for the very high class of tourist there must be luxury hotels (especially for the foreign tourists). Five stars and all-inclusive hotel resorts should be built, but instead of placing those hotels in the center and disrupting the living and natural environment, it would be more appropriate to place them in the peripheral parts of the city. This would be in accordance to idea for city zoning, which assumes placing in a parts of the city that have parameters and standards covering certain type of tourism, accompanied with logistical zoning, which assumes providing all necessary supporting services for the full functionality of a single zone (public transportation, tour guide, traditional food, etc.). This also, would lead to widening the city area, which could solve part of the problem regarding the concentration of the most of city's facilities in a very small area and the frustrating jam around.

Once, the main customers segments are identified and the value proposition is created, the next step of the process is to embed the value proposition in a viable business model in order to capture a value for the creator of a business model. To do so, we use the "business model canvas", a tool to describe how the organization creates, delivers, and captures value. In particular, the best products and services, and the most innovative value propositions could fail if there is no integrated business model that would create and deliver the value proposition to its customers in a rationale and sustainable way.

\section{Customer channels}

The next block of the business model presents the customer channels. Customer channels describe how a value proposition is communicated and delivered to a customer segment through communication, distribution, and sales channels (Osterwalder and Pigneur, 2010). This block of the business model explains that it cannot be expected the tourists to find the offer by themselves. The value proposition should be communicated and distributed 
to them in the right way-channels. The basic idea here is that the city of Ohrid with its whole tourist potential should be communicated with the different segments through the creation of original and distinctive story around the city (from travel agencies, web sites, advertisements, City Administration, Agency for Support and Development of Tourism, caterers (hoteliers, restaurants and nightclubs), to the most important stakeholders, the citizens of Ohrid). The communication, distribution and sales channels should represent integrated mix of different activities such as: on-line booking, mobile application, web portals, website of the city, a variety of constant lines by air, road and sea, as well as institutions and web sites directly related with various types of tourism.

\section{Customer relationships}

Once, the connection is established through the communication and sales channels, the real challenges for every organization is how to upgrade the interaction and more importantly how to maintain long-term relationship with its customers. In order to attract the tourist, there should be customer relationship. This block should integrate different activities and offers into one and achieve personalization of the brand called Ohrid. What is essential for creating a city brand is good relationships between municipal government and the residents of the city. This connection exists in the cities that represent successful brand stories. Since each city resident is a walking-talking advertisement, support from residents and in the city brand are attributes that the above mentioned cities possess. These cities branded themselves in ways their residents found believable, and in doing so, the brand was reinforced as truthful. This reinforcement came in many forms such as word-of-mouth, political climate perception, advertising, early public relations, and graphic design.

\section{Revenue Streams}

The aforementioned elements together create the revenues that can result from the tourism consumption. The list of revenues can be very long and wide, including different items from many different sources such as: accommodation and services included in the specific arrangement, tickets by visits to facilities, events, activities, selling souvenirs, and many other sources of revenues.

The greatest branding campaign in the world still needs a good product (in this case a good city). The brand must deliver. The characteristics of strong brands that cities need if they strive to develop as brands, are: functionality, added value and integration. The substance of value proposition (described in the central block of the business model canvas), has to be delivered (described in the right side of the business model canvas), 
but even more important it has to be created (produced), which is subject of decryption in the following, left side of the business model canvas. This side of business model canvas consist of: key resources, key activities, key partner and cost structure.

\section{Key resources}

The left side from this business model starts with the question „What does the company called Ohrid do in order to create the value proposition and to generate those revenues?” The answer firstly leads us to the block key resources. Key resources are the most important assets required to offer and deliver the previously described elements. This presents the main reasons why tourists visit Ohrid, such as: beautiful Ohrid Lake, rich historical heritage, the 365 churches, the specific architecture of Ohrid, the pleasant climate conditions and clear air, the national park Galichica. Also, there must be appropriate structure of accommodation and services (appropriate hotels with tailored offer for different customer segments, luxury hotel resorts, visible and proper regulated private accommodation, facilities and recreational attractions for different types of tourism (rural, eco, active tourism), clean and tidy beaches, and suitable infrastructure with connected roads, parking places, public transportation and etc.

\section{Key activities}

The next block of the business model canvas is composed of the most important activities an organization needs to perform well in order to create and deliver the value proposition (Osterwalder and Pigneur, 2010). In particular, this block contains the way of combining the above listed resources and coordinating the activities between different "creators" of tourism. As it is mentioned above, the activities must be integrated into one and achieve personalization of the brand called Ohrid. The city of Ohrid should be integrated in process of creation of original and distinctive story around the city (from travel agencies, web sites, advertisements, City Administration, Agency for Support and Development of Tourism, caterers (hoteliers, restaurants and nightclubs), to the most important stakeholder, the citizens of Ohrid). What many unknown or poorly branded cities forget is that sameness is boring. In order for people to get excited about living and visiting some place there must exist diversity, but always in one original and distinctive story. Some of the activities that should be undertaken for the purpose of integration and synchronization of the tourist offer of Ohrid are: collaboration and setting goals between different types of tourism, cooperation between the key stakeholders, distinctive offer of every type of tourism but integrated in one single story and brand of city of Ohrid, construction of building according to types of tourism, zoning city and 
everything else what is required for building the one and consistent brand. As a confirmation of the importance of this building block, there are the efforts and commitment of City administration, which has been already working on a project for creation of a new tourism strategy of city of Ohrid. Namely, Municipality of Ohrid in collaboration with Swiss Foundation for Technical Cooperation, has established local coordinating body for development of tourism- an entity which will unite all stakeholders in the field of tourism and work on improving the performance of all tourism stakeholders as a prerequisite for intensive tourism development.

\section{Key partners}

The "creators" of tourism that directly or indirectly affect the tourism, are placed in the block key partners. This block contains wide list of stakeholders who should act as a partners of city of Ohrid, such as: City Administration, Agency for Support and Development of Tourism, caterers (hoteliers, restaurants and nightclubs), travel agencies, clusters and institutions directly related to the different types of tourism, and finally and probably the most important stakeholder, the citizens of Ohrid). As it is mentioned above, that support from the citizens and belief in the city brand are attributes of successful stories of creation of city brand. The residents of successful cities believe in the strength and attributes of their city, and in doing so, the brand is reinforced as truthful. What is of concern regarding the citizens of Ohrid is one of the highest percent of emigration of young people in the country. Young, well-educated and very intelligent people are living the city, failing to realize their knowledge, ideas and human potentials. In this regard, the "creative class" is becoming a widely talked about and important class of individuals who are now considered almost essential to the survival of a city. This is a class of people known as "idea workers", or "creative class" is people in science, engineering, architecture, education, arts, music, and entertainment, whose economic function is to create new ideas, new technology, and/or new creative content. Studies conducted show that it is important to attract this class in order to have a highly educated and open minded city population. This class has an important role in city branding. The young people who are living in the city are the "creative class" of city of Ohrid, and the governmental officials and city administration should consider how to engage this people as a key partner for building the Ohrid as a successful brand story.

\section{Cost structure}

The latest block of the business model canvas is the block of cost structure. Cost structure describes all costs incurred to operate a business model. The maintenance of key resources and pursuing the key activities 
generates costs. There are costs for accommodation and services included in the specific arrangement, cost for facilities and recreational attractions for different types of tourism, investments in infrastructure, marketing costs and many other costs, which are crucial for functioning of the tourist business model of city of Ohrid.

\section{Conclusion}

The created tourist model of the city of Ohrid brings some interesting ideas and solutions for many contemporary issues in tourism, such as: integrated tourist offer that lasts 12 months, combined of diverse types of tourism for various customer segments, highly professional service and shared values, widely differentiated accommodation with clear targeting and positioning strategy, as well as focused tourist zones that cover certain type of tourism for pleasant stay and experience of tourists with necessary supporting services for the full functionality.

The proposed tourist model of the city of Ohrid, suggests that the key activities that should be undertaken are integration and synchronization of the rich and diversified scope of resources, such as: natural beauty/amenities, cultural and historical heritage, complex structure of accommodation and services, facilities and recreational attractions, as well as suitable infrastructure with connected roads, parking places and public transport.

The "creators" of tourism that directly or indirectly affect the tourism should be composed of a very wide list of stakeholders who act as key partners of the city of Ohrid, such as: City Administration, Agency for Support and Development of Tourism, caterers (hoteliers, restaurants and nightclubs), travel agencies, tour operators, clusters and institutions directly related to the different types of tourism, and finally and probably the most important stakeholder, the citizens of Ohrid).

The main idea is the integration into one story of the wide diversity of tourist offer for various customer segments, supported from citizens as well as from all key partners, who believe in the city brand called Ohrid.

\section{Limitations and further research}

As it is noted above, the purpose of the paper is creating distinctive value proposition and recognizable destination brand, through integration of different activities and actors in the segment of tourism by application of business model tools. The results of the research bring some interesting ideas and solutions for many contemporary issues in tourism. Nevertheless this paper basically provides some possible directions and considerations for more comprehensive research and examinations, which should create a framework for the future national strategy for tourism development. 


\section{References:}

1. American Marketing Association [dictionary]

2. Baker, B. (2007). Destination Branding for Small Cities: The Essentials for Successful Place Branding, Portland: Creative Leap Books.

3. Buhalis, D. (2000). "Marketing the competitive destination of the future”, Tourism Management, Vol. 21, Iss.1, pp.97-116.

4. Casadesus-Masanell, R.\& Ricart, J.E. (2011). "How to design a winning business model”, Harvard Business Review, Iss. JanuaryFebruary.

5. CEOs for Cities (2006) Branding Your City, Chicago.

6. Drucker, P.F. (1994). "The theory of the business”, Harvard Business Review, Iss. September-October.

7. Gardyn, R. (2002). “Packaging cities”, American Demographics Magazine, Vol.24, Iss.1, pp. 25-40.

8. Girotra, K. \& Netessine, S. (2014). "Four paths to business model innovation”, Harvard Business Review, Iss. July-August.

9. Gnoth, J. (2002). "Leveraging export brands through a tourism destination brand”, Journal of Brand Management, Vol.9, Iss.4, pp.262-280.

10. Hall, C.M. \& Mitchell, R. (2000). "Wine tourism in the Mediterranean: A tool for restructuring and development", Thunderbird International Business Review, Vol.42, Iss.4, pp.445465.

11. Johnson, M.W., Christensen, C.M. \& Kagermann, H. (2008). "Reinventing your business model”, Harvard Business Review, Iss. December.

12. Kalkstein-Silkes, C.A. (2007). Food and Food Related Festivals in Rural Destination Branding [doctoral dissertation], Indiana: Purdue University.

13. Khanna, M. (2011). “Destination branding: Tracking brand India”, Synergy, Vol.9, Iss.1, pp.40-49.

14. Macedonian tourism overcomes barriers to development, available on http://www.mia.mk

15. Magretta, J. (2002). "Why business models matter”, Harvard Business Review, Iss. May.

16. Municipality of Ohrid - Unit for local economic development

17. Murphy, P., Pritchard, M.P. \& Smith, B. (2000). “The destination product and its impact on traveler perceptions”, Tourism Management, Vol.21, Iss.1, pp.43-52.

18. Osterwalder, A. \&Pigneur, Y. (2010). Business Model Generation, New Jersey: Wiley. 
19. Osterwalder, A. \&Pigneur, Y. (2014). Value Proposition Design: How to Create Products and Services Customers Want, New Jersey: Wiley.

20. Ovans, Andrea (2015). “What Is a Business Model?”, Harvard Business Review, January.

21. "Subventions great incentive for bringing foreign tourist by travel agencies” (2016), Tourist Horizons Magazine, No.1, April.

22. Winfield-Pfefferkorn, J. (2005). The Branding OF Cities: Exploring City Branding and the Importance [Mastersthesis] 